J. clin. Path., 27, Suppl. (Roy. Coll. Path.). 7, 127-134

\title{
Tumour-associated hormonal products
}

\author{
J. LANDON, J. G. RATCLIFFE, LESLEY H. REES, AND A. P. SCOTT \\ From the Department of Chemical Pathology, St Bartholomew's Hospital, London
}

Tumour-associated hormonal products are only one example of tumour-associated antigens. Nonetheless they serve as an excellent model for the larger subject, and provide the best documented and earliest recognized examples of the release by tumours of substances not normally synthesized by their tissue of origin. There are several reasons for their early recognition: the production of biologically active hormones often causes clinically obvious effects; assay procedures have been developed for many peptide and other hormones; methods have been evolved for their extraction and purification; and, finally, the structure of many hormones has been elucidated, enabling detailed comparison with tumour hormonal products.

The earliest report of ectopic hormone production was that of Brown (1928), who noted the association of an oat-cell carcinoma of the bronchus with bilateral adrenal hyperplasia in a woman who presented with hirsutism and diabetes mellitus. More than $\mathbf{3 0}$ years later, Holub and Katz (1961) demonstrated the presence of adrenocorticotrophin (ACTH)-like material in a lung tumour, and Liddle and his colleagues (Meador, Liddle, Island, Nicholson, Lucas, Nuckton, and Luetscher, 1962) established its pathophysiological basis by their demonstration of elevated plasma and tumour ACTH and decreased pituitary ACTH levels in five cases. In the last decade, the syndrome has been recognized with increasing frequency and, by 1968 , over 100 authentic cases had appeared in the literature (Azzopardi and Williams, 1968).

Following the elucidation of the ectopic ACTH syndrome, many other ectopic humoral syndromes were recognized, some of which are summarized in table I. Furthermore, hormones have been detected in tumours in the absence of clinical syndromes
(Unger, Lochner, and Eisentraut, 1964; Fusco and Rosen, 1966; Hauger-Klevene, 1968; Ratcliffe, Knight, Besser, Landon, and Stansfeld, 1972; Weintraub and Rosen, 1972) and it is now clear that hormone production by tumours is considerably more common than hitherto recognized. This observation may have important clinical consequences in facilitating the diagnosis and management of patients with cancer. It may also have theoretical implications in understanding the mechanism of cellular differentiation.

This paper will present a few selected, non-clinical aspects of the subject and indicate some of the areas in which our ignorance is most profound. For detailed discussion of clinical aspects, readers are referred to several comprehensive reviews (Lipsett, 1968; Liddle, Nicholson, Island, Orth, Abe, and Lowder, 1969; Ross, 1968, 1972).

\section{Classification}

Tumours associated with the secretion of hormonal products can be classified into two main groups, which are summarized in table II. These are considered briefly in the following paragraphs.

The first group comprises tumours arising in endocrine glands which normally secrete the hormone under consideration. A variety of hormones may be secreted by such tumours, including peptide and protein hormones, for example, growth hormone (HGH) by eosinophilic pituitary adenomas and proinsulin and insulin by islet cell tumours of the pancreas, glycoprotein hormones, such as human chorionic gonadotrophin (HGH) by choriocarcinomas, and steroids, for example, cortisol by adrenocortical adenomas. Clearly such tumour cells retain

\begin{tabular}{ll}
\hline Syndrome & Responsible Ectopic Hormone \\
\hline Cushing's syndrome & Associated Hormonal Products \\
Inappropriate antidiuresis & ACTH \\
Hypercalcaemia & PVP \\
Gynaecomastia and precocious puberty & LTH, FSH, HCG \\
Galactorrhoea & Oxytocin, neurophysin \\
Polycythaemia & Prolactin \\
\hline
\end{tabular}

Table I Some ectopic hormonal syndromes 


\begin{tabular}{|c|c|c|}
\hline \multirow[t]{2}{*}{ Group } & \multicolumn{2}{|l|}{ Hormone-secreting Tumours } \\
\hline & Endocrine Tissue & Non-endocrine Tissue \\
\hline 1 & $\begin{array}{l}\text { Normally synthesized by tissue of origin; identical to normal } \\
\text { hormones or their precursors }\end{array}$ & \\
\hline 2 & & $\begin{array}{l}\text { Not normally synthesized by tissue of origin: } \\
\text { (1) Similar to hormones secreted by endocrine glands } \\
\text { or (2) Similar to hormones secreted by placental tissue } \\
\text { or (3) Not similar to any known hormones }\end{array}$ \\
\hline
\end{tabular}

Table II Classification of tumours that secrete hormonal products

the appropriate biosynthetic pathways, and the only way in which they differ markedly from normal endocrine cells is that their function is seldom influenced by appropriate physiological control mechanisms. This group also comprises some tumours, for example, adrenocortical carcinomas, that secrete precursors of the normal hormones, probably as a result of abnormal biosynthetic pathways. The development of assays for the majority of peptide and other hormones has proved of considerable value in the diagnosis of these tumours and also in assessing the results of therapy (see Bagshawe, Golding, and Orr, 1969). It is not, however, proposed to discuss this group of tumours any further.

The rest of this discussion concerns the second group of tumours, often of non-endocrine origin, which secrete hormonal products not normally considered to be synthesized by their tissue of origin. This group also includes tumours arising in endocrine glands, if they are secreting hormonal products distinct from those normally secreted. Such an example would be the secretion of ACTH by a pancreatic islet cell carcinoma.

Problems of classification are common. For example, some authors include pancreatic islet cell carcinomas secreting gastrin and glucagon in the second group. The difficulty arises, however, that normal pancreatic islets contain gastrin in the $\mathrm{D}$ (alpha 1$)$, cells and glucagon in the A $\left(\right.$ alpha $\left._{2}\right)$ cells (Lomský, Langr, and Vortel, 1969; Greider and McGuigan, 1971) and, in the few cases in which glucagon and gastrin have been demonstrated in islet cell carcinomas (Murray-Lyon, Cassar,Coulson, Williams, Ganguli, Edwards, and Taylor, 1971), it has not been possible to show whether this was due to the presence of both normal D and A cells in the tumour or the production of the hormones by one or different tumour cell types. Until these points are clarified it will not be possible to conclude that these are cases of ectopic glucagon or gastrin secretion.

It will be apparent from the above that a hormone may be defined as 'ectopic' when it is produced by a neoplasm derived from tissue not normally engaged in the production of that hormone. As discussed in a later section, these ectopic products are usually similar to normal peptide and protein hormones such as arginine vasopressin (AVP), ACTH, and HGH, although some may differ slightly from normal hormones on the basis of their immunological or other characteristics (Roof, Carpenter, Fink, and Gordon, 1971). Finally, some hormonal products are similar to proteins, such as human placental lactogen (HPL), normally synthesized only by placental tissue.

There are no well documented instances of the ectopic production of steroids from two carbon precursors, although breast tumours have been shown to interconvert steroid precursors in vitro (Adams and Wong, 1968; Jenkins and Ash, 1972). Thus Adams and Wong (1969) have demonstrated the formation of pregnenolone from cholesterol and of oestriol from testosterone by breast tumours, which suggests that these malignant cells contain complex, organized enzyme systems ('ectopic enzymes') analogous to ectopic hormones. Significant amounts of prostaglandin $E_{2}, F_{1}$, and $F_{2}$ alpha occur in phaeochromocytomas and medullary thyroid carcinomas (Sandler, Karim, and Williams, 1968; Williams, Karim, and Sandler, 1968), but whether steroids and prostaglandins are truly ectopic remains to be determined, since the normal biosynthetic potential of the cells from which these tumours originated has not yet been firmly established.

\section{Evidence that Tumours Synthesize Ectopic Hormonal Products}

Some of the types of evidence that tumours actually synthesize and release ectopic hormonal products can be summarized as follows: (1) association of a neoplasm with the clinical manifestations of hormone hypersecretion; (2) association of a neoplasm with elevated or inappropriate circulating hormone levels; (3) fall in circulating hormone levels and/or regression of clinical manifestations of hormone excess following removal of the tumour; (4) demonstration of hormone storage by specific immunofluorescence or by the finding of characteristic ultrastructural features, eg, neurosecretory granules, in tumour 
tissue; (5) demonstration of high hormone levels in tumour tissue; (6) no fall in circulating hormone levels and/or regression of clinical manifestations of hormone excess following removal of the usual gland of origin of the hormone; (7) demonstration of higher hormone levels in the venous effluent from, than in the arterial supply to, the tumour; (8) demonstration in vitro of (i) hormone release into the media and (ii) incorporation of labelled amino acids into a specifically identified hormone.

The literature is replete with case reports of patients presumed to have ectopic hormone syndromes, based on indirect evidence, associating a tumour with an endocrine abnormality. Great care must be taken before concluding that a particular tumour is responsible for the clinical manifestations of excessive hormone production. Thus the association, for example, of Cushing's syndrome with a bronchial neoplasm is insufficient evidence to diagnose the ectopic ACTH syndrome. The two diseases may be coincidental: the tumour may be secreting a compound that itself stimulates the endocrine gland, eg, corticotrophin-releasing factor stimulating pituitary ACTH secretion (Upton and Amatruda, 1971); finally, many disorders may stimulate the endocrine system via normal physiological control mechanisms, for example, pulmonary disease may stimulate inappropriate secretion of AVP by the hypothalamic/posterior pituitary axis (Bartter and Schwartz, 1967). Similar criticisms can frequently be levelled at any association based solely on the finding of elevated or inappropriate circulating hormone levels. The finding, in non-pregnant subjects, of circulating HPL or of some other hormone normally secreted only by the placenta is much better evidence, since such data cannot be explained on the basis of the factors listed above.

The demonstration that clinical manifestations regress and circulating hormone levels fall after removal of the tumour provides more substantive evidence. It does not exclude, however, the possibility that the tumour had been stimulating the appropriate endocrine gland rather than secreting the hormone itself. More certain evidence, available in several instances of the ectopic ACTH syndrome, is a failure of hormone levels to fall after total removal of the pituitary (Mattingly, Keane, McCarthy, and Read, 1964).

In general, we agree with the conclusion of Liddle and his colleagues (1969) that it is essential to demonstrate the presence of the hormone in either the tumour or its metastases to be sure that the association is not fortuitous. Even then, the levels found must be higher than could be due to sequestrated blood, and the possibility remains that some tumours may be able to adsorb and concentrate the hormone from the circulation.

Additional data in vivo and in vitro can be advanced as proof that tumours can synthesize ectopic hormonal products. The finding of higher levels in the venous effluent from the tumour than in its arterial supply provides such evidence, at least over the period that sampling is being continued. This has seldom been demonstrated (table III) and ACTH provides a particular problem because release from the pituitary, in response to operative stress, may obscure any small differences. Lack of precise and sensitive plasma assays may also make demonstration of small differences difficult, whilst direct sampling of the optimal anatomical site may be impossible due to a multiple venous drainage system.

The culture of tumour tissue in vitro and the demonstration that the hormone is being released into the medium provide irrefutable proof only if the amount of hormone released is greater than the amount of hormone present initially, as determined by extracting and assaying part of the tumour. Few studies in vitro of ectopic hormone production have been successful, since the amounts of hormone released into the medium may be very low and tend to decline rapidly to below the sensitivity of existing assay methods. The introduction of ultrasensitive assay methods, such as the redox assays for ACTH and LH (Chayen, Loveridge and Daly, 1972; Rees, Holdaway, McNeilly, and Chard, 1973), may help in making tissue culture conditions the best possible. Tumours in culture may also change their biosynthetic potential. Thus we have observed a tumour in which secretion of AVP was preserved for a much longer period than ACTH.

Recently, Greenberg, Beck, Martin, and Burger (1972) have demonstrated the incorporation of

\begin{tabular}{|c|c|c|c|c|}
\hline Case & Date & Author & Tumour and Site & Hormone \\
\hline $\begin{array}{l}1 \\
2 \\
3 \\
4 \\
5,6 \\
7 \\
8\end{array}$ & $\begin{array}{l}1967 \\
1968 \\
1970 \\
1970 \\
1972 \\
1972 \\
1972\end{array}$ & $\begin{array}{l}\text { Faiman et al } \\
\text { Williams } \text { et al } \\
\text { Buckle et al } \\
\text { Knill-Jones et al } \\
\text { Ratcliffe et al } \\
\text { Schteingart et al } \\
\text { Balsam et al }\end{array}$ & $\begin{array}{l}\text { Adenocarcinoma lung } \\
\text { Medullary carcinoma thyroid } \\
\text { Clear cell carcinoma kidney } \\
\text { Intrahepatic biliary tract carcinoma } \\
\text { Bronchial carcinoid } \\
\text { Adrenal medullary paraganglioma } \\
\text { Adenocarcinoma colon }\end{array}$ & $\begin{array}{l}\text { FSH, LH } \\
\text { Prostaglandins } \mathrm{E}_{2}, \mathrm{~F}_{2} a \\
\text { PTH } \\
\text { PTH } \\
\text { ACTH } \\
\text { ACTH, MSH } \\
\text { ACTH }\end{array}$ \\
\hline
\end{tabular}

Table III Cases of ectopic hormone production with an arteriovenous difference demonstrable across the tumour 
labelled amino acids into growth hormone, and George, Capen, and Phillips (1972) into vasopressin, by undifferentiated lung tumours. It should be noted, however, that due to the small amounts of labelled product, these workers were unable to identify them positively as growth hormone and vasopressin. Such a demonstration must remain as the ultimate proof.

\section{Incidence of Ectopic Hormonal Production}

The true incidence of ectopic hormonal production is not known. Cushing's syndrome was recognized in $2.8 \%$ of a consecutive series of 138 cases of oat cell lung carcinoma by Kato, Ferguson, Bennett, and Burford (1969), and in 0.5\% (Azzopardi, Freeman, and Poole, 1970) and $2 \%$ (Ross, 1968) of two other series of patients with lung tumours. In Ross's study, the incidence of inappropriate secretion of $\mathrm{ADH}$ was reported as $2 \%$. The incidence is much higher when based on biochemical parameters, thus Liddle et al (1969) demonstrated significant amounts of biologically active ACTH in six out of 78 unselected tumours $(7 \cdot 7 \%)$ whilst we (Ratcliffe et al, 1972) found biologically and immunologically active ACTH in each of 14 unselected 'control' tumours (mainly carcinomas of lung). Thirty-six per cent of these tumours had bio- or immunoactivity within the range found for tumours associated with the clinical ectopic ACTH syndrome (see fig).

Thus, the incidence of the overt ectopic humoral syndromes probably underestimates, by a wide margin, the true incidence of ectopic hormone production. In part, this may be due to a natural reluctance of the clinician to investigate patients with inoperable malignant disease and, in part, because some of the typical manifestations of hormone excess may be obscured in patients with malignant disease. Furthermore, biochemical abnormalities due to one hormone may be masked by overproduction of another. For example, with a tumour secreting both AVP and ACTH, the presence of excessive AVP secretion may be obscured by the concomitant hypercortisolism, which enhances water diuresis and the destruction of vasopressin by the liver, exerts an antagonistic action on the renal tubule, and may suppress vasopressin output from the posterior pituitary and perhaps from an ectopic site. Reduction of the hypercortisolism by adrenalectomy or aminoglutethimide therapy may lead to the appearance of the full-blown clinical ectopic AVP syndrome. In addition, the presence of a circulating ectopic hormone or hormonal product may go unnoticed because it has no easily recognizable biochemical or clinical effect, as in the case of HPL production by some lung tumours (Weintraub and Rosen, 1972)

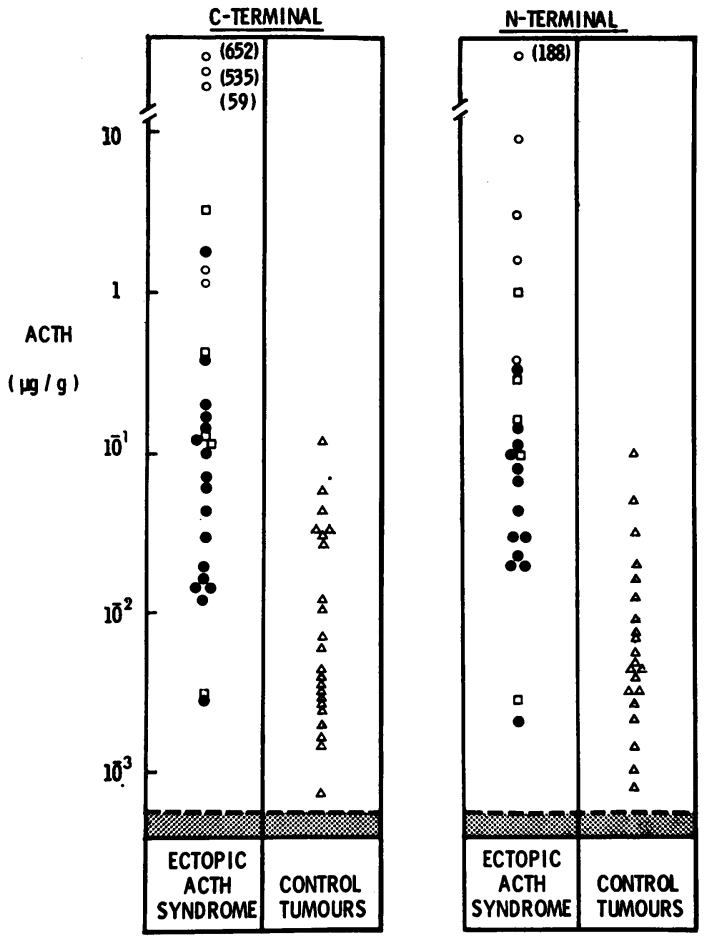

Fig Tumour immunoreactive ACTH levels in ectopic ACTH syndrome and controls.

and of corticotrophin-like intermediate lobe peptide by a variety of tumours (Bloomfield, Scott, and Ratcliffe, unpublished observations).

Other factors also cause difficulty in establishing the true incidence of ectopic hormone production. Thus, it should be recognized that the substances measured in a particular patient or extracted from a particular tumour reflect the special interests and expertise of the investigator. This may lead to a biased and misleading picture of ectopic hormone secretion, and may explain the rarity of well documented reports of multiple hormone production. Thus, the latter may be more apparent than real and the actual incidence will not be determined till a much wider search has been made for a wide variety of hormones and related products in unselected tumours.

Finally, it must be stressed that even the absence of high hormone levels in a tumour does not prove that the tumour was not synthesizing hormone. For example, a high proportion of tumours associated with the ectopic ACTH syndrome contain low concentrations of bioactive and immunoactive ACTH $(<1 \mu \mathrm{g} / \mathrm{g})$. In these cases, abnormalities in 
storage could cause release of the hormone immediately it was formed or the presence of high concentrations of proteolytic enzymes might rapidly destroy any stored hormone.

\section{Comparison of Tumour Hormonal Products with their Normal Counterparts}

Understanding of a disease depends, in part, upon whether it is due to abnormalities in molecules with which we are familiar. The study of ectopically produced hormonal products may contribute to oncological research because the detailed structure of many of their normal hormone counterparts is known. It is disappointing, therefore, that the full chemical sequence has not been determined for any 'ectopic' peptide or protein hormone, mainly because tumours contain and release relatively minute concentrations of these products. Recent improvements in the specificity of methods of purification, eg, by affinity chromatography, and in the sensitivity of methods of characterization should enable rapid progress. Furthermore, the recent demonstration that cloned human malignant melanoma cells maintain their ability to synthesize ACTH (Orth, 1973) offers a new solution to the problem of obtaining adequate quantities of hormone for chemical studies.

To date, the most successful example of structural characterization of a tumour hormonal product is that of corticotrophin-like intermediate lobe peptide from a bronchial carcinoid tumour associated with the ectopic ACTH syndrome (Ratcliffe, Scott, Bennett, Lowry, McMartin, Strong, and Walbaum, 1973). This peptide resembles 18-39 ACTH in amino acid composition and was originally isolated from rat and pig pituitaries (Scott, Bennett, Lowry, McMartin, and Ratcliffe, 1972). Apart from this study, most of the data relating to the characterization of ectopic hormones have been derived indirectly. The best data are those relating to ectopic ACTH and AVP, and will be considered in more detail.

Liddle, Givens, Nicholson, and Island (1965) listed several physicochemical properties held in common by ectopic and pituitary ACTH. These included their resistance to strong acids, their rapid inactivation by alkali, periodate (suggesting an $\mathrm{N}$-terminal serine) and certain proteolytic enzymes and their reversible inactivation by hydrogen peroxide (suggesting an important methionine residue). Both have similar biological effects including adrenal steroidogenesis, ascorbic acid depletion, cyclic AMP formation, melanocyte-stimulating activity, and lipolytic activity in the rat epididymal fat pad. Both show immunological similarities, but differ in that tumours often contain more $\mathrm{C}$ - than $\mathrm{N}$-terminal ACTH immunoactivity, whereas pituitary gland extracts contain equivalent quantities. This apparent anomaly has been resolved with the characterization of corticotrophin-like intermediate lobe peptide, which is present in normal human pituitaries in amounts too small to affect the $C: N$ ratio.

Tumour vasopressin resembles the pituitary hormone in all the test systems so far employed. Both have similar antidiuretic, vasopressor, and milk-ejecting activities, are reversibly bound by neurophysin, are inactivated by thioglycollate (suggesting that the integrity of a disulphide bond is important in maintaining biological activity), trypsin, chymotrypsin, and pregnancy plasma but are not degraded by pepsin or male plasma (Sawyer, 1967). In addition, both bind to specific antisera, several of which are sufficiently discriminating to separate LVP and AVP and it seems likely that tumour vasopressin is in fact AVP.

Most available data suggest the similarity of tumour hormones to their normal counterparts. It is now known, however, whether this holds for the relationship of hormone to precursor. Thus, Yalow and Berson (1971) have reported that all the ACTH activity in the plasma of a patient with the ectopic ACTH syndrome was in a large molecular weight form ('big' ACTH). There are also some data to suggest that certain tumour products may differ from their normal counterparts. Using a combination of physicochemical, immunological, and biological techniques, differences between ectopic MSH and pituitary MSH have been demonstrated (Shapiro, Nicholson, Orth, Mitchell, and Liddle, 1971). Although ectopic parathyroid hormone (PTH) is biologically active in partially preventing the hypocalcaemic response to parathyroidectomy in rats and has a similar sedimentation rate to purified bovine PTH in a sucrose density gradient, some tumour 'PTH' extracts do not give parallel radioimmunoassay displacement curves (Riggs, Arnaud, Reynolds, and Smith, 1971; Roof et al, 1971). Ectopic thyrotrophin-like material also shows a slight difference from pituitary TSH in its time course of activity in mice (Hennen, 1967) and the structural relationship between these glycoproteins and chorionic thyrotrophin remains to be defined. Like TSH, tumour gonadotrophins (LH, FSH, HCG) are poorly characterized, but the recent report (Franchimont, Gaspard, Reuter, and Heynen, 1972) that a variety of tumours secrete large quantities of immunoactive alpha subunits, not associated with the appropriate beta unit, suggests that the quaternary structure of the glycoprotein hormones may be abnormal. 
These differences may indicate modification of the tumour peptide in vivo by proteolytic activity or during extraction. If true differences are demonstrated, it will be important to determine whether identical hormones can be isolated from normal foetal, placental, or adult tissues or whether they are unique tumour products. Although this latter proposal seems unlikely, it would have important consequences in detecting human cancer.

\section{Hypotheses for the Cellular and Biochemical Basis of Ectopic Hormonal Production}

Several hypotheses have been advanced concerning the biochemical basis of ectopic hormone production (table IV). Thus it has been postulated, as in the 'sponge' hypothesis, that non-endocrine tumours do not actually synthesize hormones but rather adsorb preformed hormones after their release into the circulation from their normal tissue of origin. A second (termed here for convenience the 'endocrine cell' hypothesis) accepts that such tumours synthesize hormones but postulates that the cells comprising part, or all, of such tumours are endocrine in origin. If this is correct they would be equivalent to group I tumours in the classification given earlier (table II). The two other hypotheses, considered in this paper, postulate that non-endocrine tumours synthesize hormonal products, but differ as to whether this is a primary defect of the genome or of the mechanisms which control the expression of genetic information.

\section{THE 'SPONGE'}

Unger, Lochner, and Eisentraut (1964) postulated that the tumours associated with the ectopic humoral syndrome adsorb peptide hormones from the circulation, which are later liberated on cell death.

THE 'ENDOCRINE CELL'

Pearse $(1968,1969)$ has examined the histochemical and ultrastructural characteristics of the cells which comprise the peripheral endocrine gland of Feyrter (paracrine, clear cell system; Feyrter, 1972) and has shown that certain of them have the features of amine precursor uptake and decarboxylation (APUD cells). Many of the known peptide-producing cells, such as the pituitary corticotrophs, alpha ${ }_{1}$ alpha $_{2}$, and beta cells of the islets of Langerhans and the $C$ cells of the thyroid, share APUD characteristics with cells in which no defined polypeptide product has yet been recognized, including the chromaffin and argyrophil cells of the stomach and intestine and the Kultschitzky-type clear cells of the lung. It has been postulated that such cells, derived from neural ectoderm (Weichert, 1970; Le Dourain and Le Lievre, 1972), give rise to ectopic hormone-secreting tumours either as the sole cell type or as one component, not necessarily neoplastic, of a pleomorphic tumour.

\section{THE 'DEREPRESSION'}

These hypotheses assume that the genetic potential for synthesizing hormones is present in every cell, that it is normally repressed in the differentiated cell and that derepression of the appropriate part of the genome is the cause of ectopic hormone production.

The possible mechanism of derepression is obscure though, by analogy with the genetic control of microorganisms, one could postulate changes in either an operator or a regulator gene. Loss of effective repressor molecules would then give rise to a situation analogous to that seen in constitutive mutants of bacteria with unregulated expression of the affected operon (Pitot and Heidelberger, 1963). Alternatively, the presence of an appropriate inducer (corepressor) could block effective repressor activity and lead to unrestrained transcription or, as recently suggested by Ney (1973), derepression of an operon, which determined expression of a surface receptor protein, might lead to a tumour cell responding to a wide variety of inappropriate circulating factors by the continuous synthesis of the ectopic product.

\section{THE 'ABNORMAL GENOME'}

Finally it is possible that extensive base substitutions or alterations may occur in the genome of tumours, which lead to the synthesis of abnormal peptides and proteins. The release of sufficient amounts of these polypeptides could then result in the various ectopic hormonal syndromes, provided some of them con-

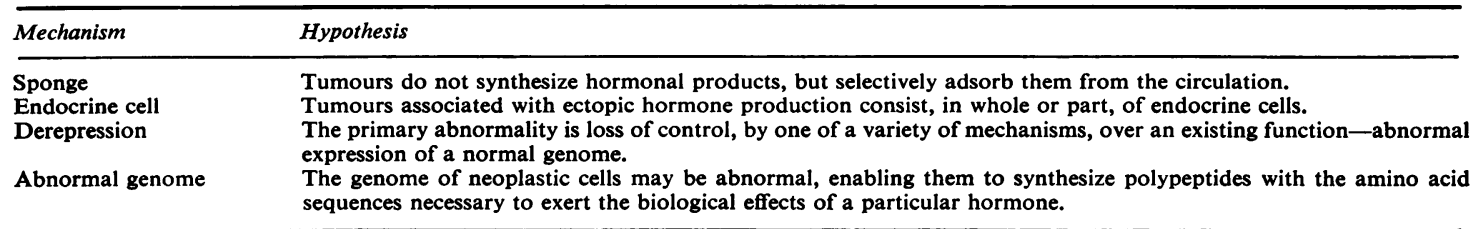

Table IV Possible mechanisms for the production of ectopic hormonal products 
tained the amino-acid sequence appropriate for the biological activity of a particular hormone.

\section{COMMENTS ON HYPOTHESES}

These hypotheses raise more problems than they solve and more accurate data are required, both concerning the ectopic hormones and their tissue of origin, before answers will emerge. At present, although it is not certain which one, or combination, of the above is correct, certain general comments can be made.

The 'sponge' hypothesis was based on the known alterations which occur in the surface properties of malignant cells. It is difficult to reconcile, however, with the fact that some tumours, associated with ectopic humoral syndromes, are only a few millimetres in diameter and do not contain necrotic tissue. Proof of synthesis de novo of hormones by these tumours is needed to refute this hypothesis finally. Similarly, proof that the structure of the various ectopic hormonal products is identical to their normal counterparts will serve to disprove the 'abnormal genome' hypothesis.

It will be much more difficult to decide between the 'endocrine cell' and the 'derepression' hypotheses, since both assume that tumours synthesize ectopic hormonal products identical to normal hormones. It could be predicted, on the basis of derepression, that any tumour cell would be capable of producing ectopic hormones, whereas more selective tumour types would be expected on the basis of the 'endocrine cell' hypothesis. In a critical analysis of their own and other data in the literature, Azzopardi and Williams (1968) found that the relationship between the histological types of tumours associated with the various ectopic hormonal syndromes was selective. For example, most cases of ectopic ACTH production are associated with tumours of foregut origin, with phaeochromocytomas and related neoplasms and with ovarian tumours whilst gonadotrophin production is usually associated with large cell adenocarcinomas of the lung and PTH production with renal and squamous cell carcinomas.

Although the majority of clinically apparent cases fall into these restricted groups, it is possible that other tumours may produce hormones, but usually in amounts insufficient to cause clinical syndromes, ie, the syndromes may be quantitative rather than qualitative. In favour of this view is the association of the ectopic ACTH syndrome and positive tissue hormone levels with adenocarcinomas of the colon (Balsam, Bernstein, Goldman, Sachs, and Rifkin, 1972) and with melanomas (Orth, 1973). Furthermore, there are difficulties in explaining the production of ectopic hormones on the basis of APUD cells alone, not least that the normal cells of origin of PTH and of the glycoprotein hormones $(\mathrm{LH}$, FSH and TSH) do not show APUD features (Pearse, 1969).

It may well be that a variety of mechanisms operate. Thus some tumours may contain cells that normally produce peptide hormones (type 2, DNA: Williams, 1969) whilst the genome for polypeptide synthesis in the cells of other tumours may be readily derepressed (type 3, DNA). In addition, the local environment may play an important role in determining these changes and, since cell proliferation itself alters the environment, this may be enough to affect gene control in labile cells (Laurence and Neville, 1972).

We gratefully acknowledge the support of the Cancer Research Campaign and the Tenovus Institute. We also thank Dr D. N. Orth for prepublication data and Dr P. J. Lowry, Miss G. Bloomfield, and the many clinicians who have contributed to these studies.

\section{References}

Adams, J. B., and Wong, M. S. F. (1968). Paraendocrine behaviour of human breast carcinoma: in vitro transformation of steroids to physiologically active hormones. J. Endocr., 41, 41-52.

Adams, J. B., and Wong, M. S. F. (1969). Desmolase activity of normal malignant human breast tissue. J. Endocr., 44, 69-77.

Azzopardi, J. G., Freeman, E., and Poole, G. (1970). Endocrine and metabolic disorders in bronchial carcinoma. Brit. med. J., 4, 528-529.

Azzopardi, J. G., and Williams, E. D. (1968). Pathology of 'nonendocrine' tumors associated with Cushing's syndrome. Cancer (Philad.), 22, 274-286.

Bagshawe, K. D., Golding, P. R., and Orr, A. H. (1969). Choriocarcinoma after hydatidiform mole: studies related to effectiveness of follow-up practice after hydatidiform mole. Brit. med. J., 3, 733-737.

Balsam, A., Bernstein, G., Goldman, J., Sachs, B. A., and Rifkin, H. (1972). Ectopic adrenocorticotrophin syndrome associated with carcinoma of the colon. Gastroenterology, 62, 636-641.

Bartter, F. C., and Schwartz, W. B. (1967). The syndrome of inappropriate secretion of antidiuretic hormone. Amer. J. Med., 42, 790-806.

Brown, W. H. (1928). A case of pluriglandular syndrome. 'Diabetes of bearded women.' Lancet, 2, 1022-1023.

Buckle, R. M., McMillan, M., and Mallinson, C. (1970). Ectopic secretion of parathyroid hormone by a renal adenocarcinoma in a patient with hypercalcaemia. Brit. med. J., 4, 724-726.

Chayen, J., Loveridge, N., and Daly, J. R. (1972). A sensitive bioassay for adrenocorticotrophic hormone in human plasma. Clin. Endocr., 1, 219-233.

Faiman, C., Colwell, J. A., Ryan, R. J., Hershman, J. M., and Shields, T. W. (1967). Gonadotrophin secretion from a bronchogenic carcinoma. New Engl. J. Med., 277, 1395-1399.

Feyrter, F. (1972). The clear cell system: the peripheral endocrine (paracrine) glands. In Endocrinology 1971: Proceedings of the Third International Symposium, London, edited by Selwyn Taylor, pp. 134-144. Heinemann, London.

Franchimont, P., Gaspard, U., Reuter, A., and Heynen, G. (1972). Polymorphism of protein and polypeptide hormones. Clin. Endocr., 1, 315-336.

Fusco, F. D., and Rosen, S. W. (1966). Gonadotropin producing anaplastic large-cell carcinomas of the lung. New Engl. J. Med., 275, 507-515.

George, J. M., Capen, C. C., and Phillips, A. S. (1972). Biosynthesis of vasopressin in vitro and ultrastructure of a bronchogenic carcinoma. J. clin. Invest., 51, 141-148.

Greenberg, P. B., Beck, C., Martin, T. J., and Burger, H. G. (1972). 
Synthesis and release of human growth hormone from lung carcinoma in cell culture. Lancet, 1, 350-352.

Greider, M. H., and McGuigan, J. E. (1971). Cellular localisation of gastrin in the human pancreas. Diabetes, 20, 389-396.

Hauger-Klevene, J. H. (1968). Asymptomatic production of ACTH: radioimmunoassay in squamous cell, oat cell and adenocarcinoma of the lung. Cancer (Philad.), 22, 1262-1267.

Hennen, G. (1967). Characterization of a thyroid-stimulating factor in a human cancer tissue. J. clin. Endocr., 27, 610-614.

Holub, D. A., and Katz, F. H. (1961). A possible etiologic link between Cushing's syndrome and visceral malignancy. Clin. Res., 9, 194.

Jenkins, J. S., and Ash, A. (1972). Metabolism of testosterone by human breast tumours. Lancet, 2, 513-514.

Kato, Y., Ferguson, T. B., Bennett, D. E., and Burford, T. H. (1969). Oat cell carcinoma of the lung: a review of 138 cases. Cancer (Philad.), 23, 517-526.

Knill-Jones, R. P., Buckle, R. M., Parsons, D. M., Calne, R. Y., and Williams, R. (1970). Hypercalcemia and increased parathyroidhormone activity in a primary hepatoma. New Engl. J. Med., 282 704-708.

Le Dourain, N., and Le Lievre, C. (1972). Demonstration of the neural origin of the ultimobranchial body glandular cells in the avian embryo. In Endocrinology, 1971: Proceedings of the Third International Symposium, London, edited by Selwyn Taylor, pp. 153-163. Heinemann, London.

Laurence, D. J. R., and Neville, A. M. (1972). Functional pathological aspects of the para-endocrine syndrome. In Endocrinology 1971: Proceedings of the Third International Symposium, London, edited by Selwyn Taylor, pp. 225-235. Heinemann, London.

Liddle, G. W., Givens, J. R., Nicholson, W. E., and Island, D. P. (1965). The ectopic ACTH syndrome. Cancer Res., 25, 1057-1061.

Liddle, G. W., Nicholson, W. E., Island, D. P., Orth, D. N., Abe, K., and Lowder, S. C. (1969). Clinical and laboratory studies of ectopic humoral syndromes. Rec. Progr. Hormone Res., 25, 283-314.

Lipsett, M. B. (1968). Hormonal syndromes associated with neoplasia. Advanc, metab. Dis., 3, 111-152.

Lomský, R., Langr, F., and Vortel, V. (1969). Immunohistochemical demonstration of gastrin in mammalian islets of Langerhans. Nature (Lond.), 223, 618-619.

Mattingly, D., Keane, P. M., McCarthy, C. F., and Read, A. E. (1964). Adrenocortical hyperfunction and oat-cell carcinoma of the bronchus. Bristol med-chir. J., 79, 6-14.

Meador, C. K., Liddle, G. W., Island, D. P., Nicholson, W. E., Lucas, C. P., Nuckton, J. G., and Luetscher, J. A. (1962). Cause of Cushing's syndrome in patients with tumors arising from 'non-endocrine' tissue. J. clin. Endocr., 2, 693-703.

Murray-Lyon, I. M., Cassar, J., Coulson, R., Williams, R., Ganguli, P. C., Edwards, J. C., and Taylor, K. W. (1971). Further studies on streptozotocin therapy for a multiple-hormone-producing islet cell carcinoma. Gut, 12, 717-720.

Ney, R. L. (1973). Inappropriate adenyl cyclase of certain endocrine tumours. In Proceedings of the IVth International Congress of Endocrinology. Excerpta Medica, Amsterdam, in press.

Orth, D. N. (1973). Establishment of human malignant melanoma clonal cell lines that secrete ectopic adrenocorticotrophin. Nature [new Biol.], 241, 26-28.

Pearse, A. G. E. (1968). Common cytochemical and ultrastructural characteristics of cells producing polypeptide hormones (the APUD series) and their relevance to thyroid and ultimobranchial C cells and calcitonin. Proc. roy. Soc. A., 170, 71-80.

Pearse, A. G. E. (1969). The cytochemistry and ultrastructure of polypeptide-hormone producing cells of the APUD series and the embryologic, physiologic and pathologic implications of the concept. J. Histochem. Cytochem., 17, 303-313.

Pitot, H. C., and Heidelberger, C. (1963). Metabolic regulatory circuits and carcinogenesis. Cancer Res., 23, 1694-1700.

Ratcliffe, J. G., Knight, R. A., Besser, G. M., Landon, J., and Stansfeld, A. G. (1972). Tumour and plasma ACTH concentrations in patients with and without the ectopic ACTH syndrome. Clin. Endocr., 1, 27-44.

Ratcliffe, J. G., Scott, A. P., Bennett, H. P. J., Lowry, P. J., McMartin, C., Strong, J. A., and Walbaum, P. R. (1973). Production of a corticotrophin-like intermediate lobe peptide and of corticotrophin by a bronchial carcinoid tumour. Clin. Endocr., 2, 51-55.

Rees, L. H., Holdaway, I. M., McNeilly, A. S., and Chard, T. (1973). A new, bioassay for luteinising hormone. (Abstr.) $J$. Endocr., 58, xviii.

Riggs, B. L., Arnaud, C. D., Reynolds, J. C., and Smith, L. H. (1971) Immunologic differentiation of primary hyperparathyroidism from hyperparathyroidism due to non-parathyroid cancer. $J$. clin. Invest., 50, 2079-2083.

Roof, B. S., Carpenter, B., Fink, D. J., and Gordon, G. S. (1971) Some thoughts on the nature of ectopic parathyroid hormones. Amer. J. Med., 50, 686-691.

Ross, E. J. (1968). The cancer cell as an endocrine organ. In Recent Advances in Endocrinology, edited by V. H. T. James, 8th ed., pp. 293-327. Churchill, London.

Ross, E. J. (1972). Endocrine and metabolic manifestations of cancer. Brit. med. J., 1, 735-738.

Sandler, M., Karim, S. M. M., and Williams, E. D. (1968). Prostaglandins in amine-peptide-secreting tumours. Lancet, 2 1053-1055.

Sawyer, W. H. (1967). Pharmacological characteristics of the antidiuretic principle in a bronchogenic carcinoma from a patient with hyponatremia. J. clin. Endocr., 27, 1497-1499.

Schteingart, D. E., Conn, J. W., Orth, D. N., Harrison, T. S., Fox J. E., and Bookstein, J. J. (1972). Secretion of ACTH and MSH by an adrenal medullary paraganglioma. J. clin. Endocr. 34, 676-683.

Scott, A. P., Bennett, H. P. J., Lowry, P. J., McMartin, C., and Ratcliffe, J. G. (1972). Corticotrophin-like intermediate lobe peptide-a new pituitary and tumour peptide. J. Endocr., 55, xxxvi-xxxvii.

Shapiro, M., Nicholson, W. E., Orth, D. N., Mitchell, W. M., and Liddle, G. W. (1971). Differences between ectopic MSH and pituitary MSH. J. clin. Endocr., 33, 377-381.

Unger, R. H., Lochner, J. de V., and Eisentraut, A. M. (1964) Identification of insulin and glucagon in a bronchogenic metastasis. J. clin. Endocr., 24, 823-831.

Upton, G. V., and Amatruda, T. T. Jr., (1971). Evidence for the presence of tumor peptides with corticotropin-releasing factor-like activity in the ectopic ACTH syndrome. New Engl. J. Med., 285, 419-424.

Weichert, R. F. (1970). The neural ectodermal origin of the peptidesecreting endocrine glands. Amer. J. Med., 49, 232-241.

Weintraub, B. D., and Rosen, S. W. (1972). Ectopic production of human chorionic somatomammotropin by non-trophoblastic cancers. J. clin. Endocr., 32, 94-101.

Williams, E. D. (1969). Tumours, hormones, and cellular differentiation. Lancet, 2, 1108-1110.

Williams, E. D., Karim, S. M. M., and Sandler, M. (1968). Prostaglandin secretion by medullary carcinoma of the thyroid. Lancet, 1, 22-23.

Yalow, R. S., and Berson, S. A. (1971). Size heterogeneity of immunoreactive human ACTH in plasma and in extracts of pituitary glands and ACTH-producing thymoma. Biochem. biophys. Res. Commun., 44, 439-445. 